\title{
Erzählung und Briefe im johanneischen Kreis
}

\author{
Hrsg. v. Uta Poplutz u. Jörg Frey
}

Erzählung und Briefe im johanneischen Kreis

\section{UTA POPLUTZ} und JÖRG FREY

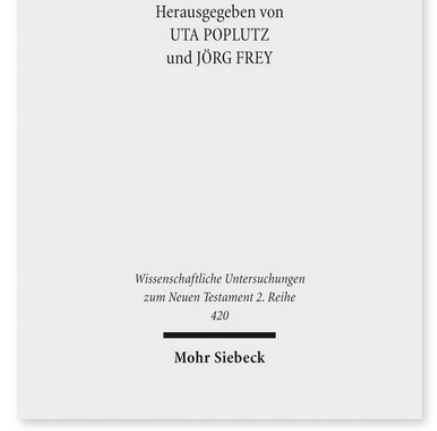

2016. VIII, 305 Seiten. WUNT II 420

SBN 978-3-16-154669-3

DOI 10.1628/978-3-16-154669-3

eBook PDF 104,00€

ISBN 978-3-16-154292-3

fadengeheftete Broschur 104,00€
Das Verhältnis von Johannesevangelium und Johannesbriefen ist in literarischer wie sachlich-theologischer Hinsicht nach wie vor strittig. Der vorliegende Band versammelt Beiträge, die diesem Verhältnis anhand unterschiedlicher Themenkomplexe nachgehen, und weitere Detailstudien zum vierten Evangelium und zu den Johannesbriefen. Neben den Fragen des gegenseitigen Verhältnisses narrativer und epistolarer Formen und der Funktion narrativer Elemente in den Johannesbriefen werden die Themen von 'Doketismus' und 'Antidoketismus', das Problem der Gemeindemähler und Fragen von Christologie, Sündentilgung und Sündlosigkeit im Vergleich behandelt. Hinzu kommen Studien zur Mimesis und Ethik im ersten Johannesbrief, zu Plot und Dramaturgie des Evangeliums sowie zum Gartenmotiv und zur Todesstunde Jesu.

Inhaltsübersicht

\section{Erzählstrukturen des Evangeliums}

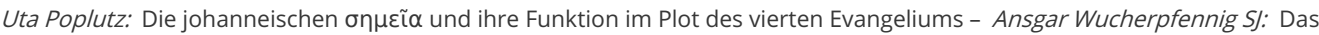
Johannesevangelium und die antike Tragödie - Igna Kramp CJ: »Habe ich Dich nicht mit ihm im Garten gesehen?« (Joh 18,26). Jesu Jünger in Joh 18,1f. und die antiken Philosophenschulen im Garten

\section{Briefliche und narrative Formen}

Johannes Beutler SJ: Das Kernproblem der Johannesbriefe in der Rezeption des Johannesevangeliums in Briefform - Christina Hoegen-Roh/s: Wovon erzählen die Johannesbriefe? Beobachtungen zu Erzählstücken im Brief und zu deren kommunikativer Pragmatik - Wolfgang Grünstäudl: Geistliches Evangelium und Katholische Briefe. Johanneische Intertextualität im Spiegel frühchristlicher Rezeption

\section{Theologische Aspekte}

Jörg Frey: Die johanneische Theologie zwischen 'Doketismus' und 'Antidoketismus'. Auseinandersetzungen und Trennungsprozesse im Hintergrund der johanneischen Schriften und ihrer Rezeption - Jan Heilmann: Antidoketische Mahltheologie in den johanneischen Schriften? - Hans-UIrich Weidemann: Das Kommen im Fleisch und die Wegnahme der Sünde: Christologie und Hamartologie in den Johannesbriefen - Ismo Dunderberg: Sin, Sinlessness, and the Limits of a

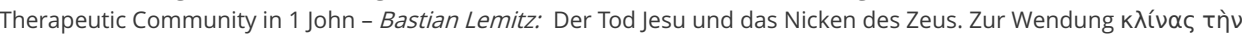

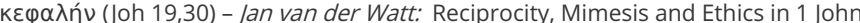

Uta Poplutz Geboren 1971; 2009-10 Vertretungsprofessur für Neues Testament an der Universität Mainz; seit 2010 Lehrstuhlinhaberin für Biblische Theologie mit dem Schwerpunkt Exegese und Theologie des Neuen Testaments an der Bergischen Universität Wuppertal.

https://orcid.org/0000-0002-6136-8621

Jörg Frey Geboren 1962; 1996 Promotion; 1998 Habilitation; Professur für neutestamentliche Wissenschaft mit den Schwerpunkten Antikes Judentum und Hermeneutik an der Theologischen Fakultät der Universität Zürich und Research Associate der University of the Free State, Bloemfontein/ZA. https://orcid.org/0000-0001-6628-8834

\section{Jetzt bestellen:}

https://mohrsiebeck.com/buch/erzaehlung-und-briefe-im-johanneischen-kreis-9783161546693?no cache=1 order@mohrsiebeck.com Telefon: +49 (0)7071-923-17

Telefax: +49 (0)7071-51104 